\title{
FEMINIST HERMENEUTICS AND EVANGELICAL CONCERNS: THE RAPE OF DINAH AS A CASE STUdY
}

\author{
Robin Parry
}

\begin{abstract}
Summary
The article begins by outlining the challenge feminist hermeneutics poses for traditional notions of biblical authority. Genesis 34 is set out as a case study for displaying feminist interpretations that read with the narrator but against patriarchal interpreters and those which read against the narrator himself. I argue that a 'high view' of Scripture can accommodate many of the concerns raised by feminist critics of biblical narrative. It is, however, maintained that an evangelical hermeneutic will not easily be able to endorse an interpretation that stands over against the stance of a biblical narrator. ${ }^{1}$
\end{abstract}

It is traditionally assumed by evangelical readers of the Bible that the narratives in the OT are ethically beneficial and that a Christian hermeneutic will be primarily a hermeneutic of faith and trust. However, things are not quite as simple as that, and recent feminist critics have been amongst those who have approached the biblical text first and foremost with a hermeneutic of suspicion. They consider the text of the Bible to be both patriarchal and androcentric and thus potentially harmful to women. Many would say that rather than uncritically opening ourselves to be shaped by the stories we ought to expose some of them as oppressive and damaging even if they are, in other ways, liberating. This challenge cuts deeply and simply cannot be ignored. The present article is an attempt to maintain the centrality of the canon in Christian ethics whilst trying to take the problems posed by androcentrism and patriarchy within the Bible

1 This article is a shortened version of Appendix 3 from my Ph.D. thesis, Using Genesis 34 in Christian Ethics: A Case Study in the Christian Ethical Appropriation of Old Testament Narratives (University of Gloucestershire, 2001). 
seriously. The following reflections begin and proceed from within a fairly conservative Christian tradition. This interpretative community and its tradition forms the sedimentation upon which I hope that creative interpretative innovation can take place as that tradition comes into dialogue with feminist scholarship.

The focus will be on Genesis 34 but I shall have to set my reflections on that passage within a broader set of considerations. Section I gives a brief introduction to feminist interpretation whilst Section II outlines feminist concerns with Genesis 34 in particular. In Section III, I defend the continuing usefulness of Genesis 34 in Christian ethics whilst attempting to learn important lessons from feminist schools of thought. I believe that although initially feminist hermeneutics of suspicion seem to undermine the normative use of scripture in Christian ethics they can open up fruitful ways of ethically reading stories which the Christian can welcome.

\section{The Challenge of Feminist Hermeneutics}

Feminism is a broad family of related but different positions. Consequently, feminist readers of biblical texts are often at variance with each other both in terms of conclusions and methodology. However, according to Katherine Doob Sakenfeld 'the beginning point, shared with all feminists studying the Bible, is appropriately a stance of radical suspicion'. ${ }^{2}$ This is because women's experiences have been excluded (a) from the official interpretations of the Bible, and often (b) from the Bible itself making the Bible a powerful tool in the oppression of women. Letty Russell writes that, "it has become abundantly clear that the scriptures need liberation, not only from existing interpretations but also from the patriarchal bias of the texts themselves'. ${ }^{3}$ Similarly, Fiorenza thinks that the Bible is 'authored by men, written in androcentric language, ${ }^{4}$ reflective of

2 K.D. Sakenfeld, 'Feminist Uses of Biblical Materials' in L. Russell (ed.), Feminist Interpretation of the Bible (Philadelphia: Westminster, 1985), 55.

3 L. Russell, 'Authority and the Challenge of Feminist Interpretations' in Russell (ed.), Feminist Interpretation, 11.

4 Patriarchy is a surprisingly difficult notion to pin down but it is usually seen as a dominance of men over women in the power relations of a society as reflected in public institutions such as government, marriage, the law, religion, education, labour and so on. This is seen by feminists as oppressive for women and necessarily evil in that it is a primary structure of human alienation and exploitation. Androcentrism is the claim that texts are written from the perspective of men. Clearly one could have texts which reflect patriarchal 
male experience, selected and transmitted by male religious leadership. Without question the Bible is a male book.'

Feminist interpreters have been keenly aware of the uses to which the Bible has been put and the problem of biblical authority has never been far from the surface. Ruether says:

The Bible was shaped by males in a patriarchal culture, so many of its revelatory experiences were interpreted by men from a patriarchal perspective. The ongoing interpretation of these revelatory experiences and their canonisation further this patriarchal bias by eliminating traces of female experience or interpreting them in an androcentric way. The Bible, in turn, becomes an authoritative source for the justification of patriarchy in Jewish and Christian society. ${ }^{6}$

How can a text like this be authoritative? Christian and Jewish feminists have had to struggle with this question since the Bible is the foundational text for both faiths and cannot simply be dismissed.

Sakenfeld ${ }^{7}$ presents a typology of the views of feminist biblical scholars on biblical authority. At one end of the spectrum she places Fiorenza who argues that the maleness of the Bible makes it impossible for it to form the basis for a transcontextual critical principle. That honour belongs to the experience of oppressed women according to which biblical texts are interpreted and evaluated. The Bible stands and falls as measured against this standard and cannot itself be considered authoritative. ${ }^{8}$ At the other end of the spectrum are the evangelical feminists who wish to

structures but which do so from women's perspectives. However, biblical texts usually discuss issues of war or the royal court or the Temple which are the domain of men and it is not surprising to find that such texts are both patriarchal and androcentric. Thus the biblical text gives the impression that Ancient Israel was far more oppressive of women than it actually was (so C. Meyers, Discovering Eve: Ancient Israelite Women in Context [Oxford: OUP, 1988]). Even when women come into the frame they are often seen from a male perspective and this may pose more of a problem than the patriarchal social structures themselves. My comments shall thus focus on androcentrism and only make passing reference to the problem of patriarchy.

5 Quoted in A. Thistleton, New Horizons in Hermeneutics: The Theory and Practice of Transforming Biblical Reading (Exeter: Paternoster, 1992), 442-43. The claim is not that the Bible sets out to consciously exclude women but simply that it reflects 'a culturally inherited and deep-rooted gender bias' (C. Exum, 'Murder They Wrote: Ideology and the Manipulation of Female Presence in Biblical Narrative' in A. Bach (ed.), The Pleasure of Her Text, [Philadelphia: Trinity Press International, 1990], 59).

6 R.R. Ruether, 'Feminist Interpretation: A Method of Correlation' in Russell (ed.), Feminist Interpretation, 116 (italics mine).

7 K.D. Sakenfeld, 'Feminist Perspectives on the Bible and Theology: An Introduction to Selected Issues and Literature', Interpretation 42 (1988) 5-18.

8 See Thistleton, New Horizons, 442-50, for a critique of Fiorenza. 
maintain as much of a traditional view of the Bible's authoritative status as possible.

Between the poles one could place Letty Russell, ${ }^{9}$ Mary Ann Tolbert ${ }^{10}$ and Phyllis Bird ${ }^{11}$ who see scripture as authoritative in so far as it makes sense of their experience or mediates God's liberating word for the oppressed. Farley similarly argues that the truth claims of the biblical witness simply cannot be believed unless they 'ring true' to the experience of women. ${ }^{12}$ The authority of scripture is redefined by Russell, as the 'authority to evoke consent' rather than as an extrinsic authority ${ }^{13}$ thus the locus of authority shifts from text to reader. ${ }^{14}$ David Clines has even suggested that the notion of authority should be abandoned by feminists altogether as he sees it as a male notion ill fitted to feminist perspectives. ${ }^{15}$ This would be a dramatic shift away from the Christian tradition and is going unnecessarily far for some Christian feminists. ${ }^{16}$

Perhaps the most useful typology of feminist responses to the Bible is that of Carolyn Osiek ${ }^{17}$ who discerns five basic stances: 18

(a) The Rejectionist. The Bible is rejected as authoritative perhaps along with Christianity itself (if the Christian tradition is seen as irredeemable). ${ }^{19}$

(b) The Loyalist. The Bible cannot be rejected under any circumstances. Two possibilities open up for the loyalist: one can reinterpret 'oppressive' texts in non-oppressive ways, seeing the

9 See L. Russell, Feminist Interpretation.

10 See M.A. Tolbert, 'Protestant Feminists and the Bible: On the Horns of a Dilemma' in A. Bach (ed.), Pleasure of Her Text, 5-23.

11 See P. Bird, 'Biblical Authority' in P. Bird, Missing Persons and Mistaken Identities: Women \& Gender in Ancient Israel (Minneapolis: Fortress, 1997).

12 M. Farley, 'Feminist Consciousness \& the Interpretation of Scripture' in Russell (ed.), Feminist Interpretation, 43.

13 Russell, Feminist Interpretation, 141.

14 Russell, Feminist Interpretation, 141.

15 D.J.A. Clines, 'What Does Eve Do to Help? And Other Irredeemably Androcentric Orientations in Genesis 1-3' in D.J.A. Clines, What Does Eve Do to Help? (Sheffield: Sheffield Academic, 1990), 45-48.

16 E.g. P. Bird, Missing Persons, 260-61.

17 C. Osiek, 'The Feminist and the Bible: Hermeneutical Alternatives' in A.Y. Collins (ed.), Feminist Perspectives on Biblical Scholarship (Atlanta: Scholars', 1985), 99-100. The typology is adopted by L. Schottroff, S. Schroer \& M.T. Wacker in ch. 2.

18 For a different typology see Sakenfeld, 'Feminist Uses'.

19 Osiek, 'The Feminist and the Bible', 97-99. Mary Daly is the most obvious writer in this category. 
problem not with the text but with its readers, ${ }^{20}$ or one could opt for the complementarian position which, strictly speaking, is not a feminist position. ${ }^{21}$

(c) The Revisionist. The Bible and the Christian tradition, it is argued, have been stamped by the patriarchal culture in which they arose but they are not essentially patriarchal and can be reformed. The 'submerged female voices' of women hidden behind text and tradition can be recovered from scraps of linguistic, rhetorical and narrative evidence. The intention is to reconstruct, as far as possible, the lives of ordinary Israelite women at different periods of the nation's history. ${ }^{22}$ One may also try to bring to the surface often ignored texts which present women in a more positive light. ${ }^{23}$ The revisionist, along with the rejectionist and the liberationist, may also highlight the androcentric and patriarchal dimensions of biblical texts in order to show how women are often ignored or presented from men's perspectives. ${ }^{24}$ Some put biblical texts under the critical eye of psychoanalytic theory to uncover subconscious themes. ${ }^{25}$ The aim of such studies is often, at least partially, to subvert such texts and undermine their authority. Such studies may then 'playfully' reimagine the story from the perspective of the women. ${ }^{26}$

20 This is the main strategy of evangelical feminists. For non-evangelical examples, see Meyers on Gn. 3:16 (Discovering Eve, ch. 5); Trible on Gn. 2 (P. Trible, God and the Rhetoric of Sexuality [London: SCM, 1978]).

21 Osiek, 'The Feminist and the Bible', 99-100.

22 Carol Meyers' magnificent study, Discovering Eve (1988) is a classic example of this approach. See too Phyllis Bird's, 'The Place of Women in the Israelite Cultus' in Bird, Missing Persons.

23 For example, C. Exum, "You Shall Let Every Daughter Live": A Study of Ex 1:8-2:10', Semeia 28 (1983) 63-82. Exum still thinks that Ex. 1-2 has a very positive portrayal of women yet she now thinks that this too supports patriarchy for the message sent out is: 'Stay in your place in the domestic sphere; you can achieve important things there. The public arena belongs to men; you do not need to look beyond motherhood for fulfilment' (C. Exum, 'Second Thoughts about Secondary Characters: Women in Exodus 1:8-2:10' in A. Brenner [ed.], A Feminist Companion to Exodus to Deuteronomy [Sheffield: Sheffield Academic, 1994], 75-87). Exum goes too far here. The text does not strongly subvert patriarchy but neither does it set out to reinforce it. I simply cannot hear what Exum thinks she hears in the story.

24 A. Bach (ed.), Women in the Hebrew Bible: A Reader (London: Routledge, 1999), xiv-xv.

25 See for instance, I. Rashkow, The Phallacy of Genesis: A FeministPsychoanalytic Approach (Louisville: Westminster/John Knox, 1993) and C. Exum, 'Who's Afraid of "The Endangered Ancestress"?' in A. Bach (ed.), Women in the Hebrew Bible, 141-56.

26 See e.g. Alice Bach's, 'With a Song in Her Heart: Listening to Scholars Listening for Miriam' in Bach (ed.), Women in the Hebrew Bible, 419-27. 
(d) The Sublimationist. The 'feminine principle' of life-giving and nurturing are glorified and the tradition is scoured for feminine symbols of God and the church. ${ }^{27}$

(e) The Liberationist. To consider the Bible generally looking for theological perspectives which can be used to critique patriarchy (e.g. new creation, shalom, prophetic critique of oppression, koinonia). The central message of the Bible is seen to be that of human liberation motivated by eschatological hope. Letty Russell finds a biblical basis and motivation for her liberationist message 'in God's intention for the mending of all creation' 28 and Ruether seeks strands of cultural critique from Israel's prophets with which to attack patriarchy. ${ }^{29}$ Both, however, take the starting point of a feminist ideology which comes from beyond the text and is brought to it with the hope of correlating the feminist critical principle with one internal to scripture..$^{30}$

Clearly these strategies, or at least (b)-(e), need not be seen as in conflict and one could embrace some combination of each. I shall make use of selected strategies from the loyalist, the revisionist and the liberationist, arguing that they not only contribute to reading the Bible ethically but that they are consistent with a 'high' view of scripture.

\section{Feminist Readings of Genesis 34: Restoring Dinah's Honour}

Feminists can read with the biblical text and against androcentric interpreters and/or against the biblical text itself. Both strategies have been used to attempt to restore both Dinah and her honour in recent work.

27 Osiek, 'The Feminist and the Bible', 101-102. Mary Gray's book Redeeming the Dream: Feminism, Redemption and the Christian Tradition (London: SPCK, 1989) which seeks for feminine metaphors of atonement in the tradition to replace dominant 'male' ones could be seen as 'sublimationist'.

28 Russell, Feminist Interpretation, 138. A recent collection of essays in honour of Letty Russell picks up this new creation theme: M. Farley \& S. Jones (eds.), Liberating Eschatology: Essays in Honour of Letty Russell (Louisville: Westminster/John Knox, 1999). See also my review of this book in European Journal of Theology 10 (2001) 1, 76-77.

29 R.R. Ruether, Sexism \& God-Talk: Towards a Feminist Theology (London: SCM, 1983).

30 Ruether, 'Feminist Interpretation'. 


\section{Reading with the Text but against the Classical Interpreters}

On reading the history of the interpretation of Genesis 34 one is struck by the fact that an element of only minor interest to the narrator of the story, Dinah's 'going out to see the daughters of the land', becomes a matter of central concern to both Jewish and Christian interpreters. Without doubt past interpretations of Genesis 34 have reflected the perspectives of the male interpreters for 'classical' readings of the story often blame Dinah for the massacre. ${ }^{31}$ Consider Aalders' 1981 Christian commentary on Genesis where we read, 'We can surmise that [Dinah] also had some natural desires to be seen by the young men of the city as well ... It was disturbing that Dinah would so flippantly expose herself to the men of this pagan city ... As a matter of fact, Dinah was far more at fault for what had happened than anyone else in the City of Shechem.' 32 All interpreters agree that Dinah was a young woman who went out alone in a dangerous place and that, at very least, this was unwise. Beyond that there is divergence. Some see Dinah as 'asking for it' by being deliberately provocative ${ }^{33}$ whilst others are more sympathetic towards her. ${ }^{34}$ Some see Dinah's act as a rebellion against her parents ${ }^{35}$ whilst others see her acting with parental permission. ${ }^{36}$ Still others see her sin as enjoyment of the illicit sexual encounter with Shechem. ${ }^{37}$ The morals drawn from the story are simple: First, that parents should ensure that daughters stay in the

31 So Genesis Rabbah LXXX:II h-i, III f-g; Bernard of Clairvaux (Selected Works [ET G.R. Evans, New York: Paulist, 1987, written 1125], 124); Ancrene Wisse (Anchoritic Spirituality [New York: Paulist, A. Savage \& N. Watson, 1991, written between 1200 and 1230], 68); J. Calvin (A Commentary on Genesis [ET J. King, London: Banner of Truth, 1965, written 1554], 218).

32 G.C. Aalders, Genesis Vol. 2 (ET J. Vriend; Grand Rapids: Zondervan, 1981), 154, 159 (italics mine).

33 So Genesis Rabbah LXXX:I; LXXX:IV.4-5; St Gregory's Pastoral Rule XXIX; Ancrene Wisse (17, 67-68); Matthew Henry, An Exposition of the Five Books of Moses (London, 1725), 112, 114.

34 Martin Luther, Luther's Works (Vol. 6, St Louis: Concordia \& Philadelphia: Fortress, 1986, written in 1542/43), 187-88, 192, 194. On Luther see especially J.A. Schroeder, 'The Rape of Dinah: Luther's Interpretation of a Biblical Narrative', Sixteenth Century Journal XXVIII/3 (1997) 775-91.

35 So Luther, op. cit., 192-94.

36 Genesis Rabbah blames Jacob for letting Dinah go.

37 So Glossa Ordinaria (Schroeder, 'Luther's Interpretation', 779-80); Genesis Rabbah LXXX:XI; Richard of Saint Victor (Schroeder, 'Luther's Interpretation', 780); Ancrene Wisse, 68; Matthew Henry implies it (Exposition, 112). Luther took the opposite view-that the rape was not pleasurable for Dinah but was a crime against her. 
home in safety. ${ }^{38}$ Second, that women should avoid both curiosity and allowing men to see them. ${ }^{39}$

Two recent studies helpfully exemplify contrasting feminist attempts to read Genesis 34 with the text but against androcentric interpreters. The first is that of Dana Nolan Fewell and David Gunn (1991) whilst the second is that of Susanne Scholz (1998).

Fewell and Gunn criticise Meir Sternberg ${ }^{40}$ for reading the story through androcentric, 'action-man' glasses. He fails to see that the ideology of the reader plays a critical role in the sense that is made of a text. ${ }^{41}$ Against Sternberg they propose a feminist reading of the text which makes as much, if not more, sense of it as his. ${ }^{42}$ As far as Dinah is concerned they argue that the narrator in v. 2 may be storing up sympathy for her, the victim, rather than her brothers, as Sternberg thinks. ${ }^{43}$ At the very least, as readers with a horror at the crime of rape, we cannot help but feel for Dinah. ${ }^{44}$ However, Shechem in v. 3 calms her fears and, out of genuine love for her, he promises to take care of her. This is a surprising sequel to the rape and it complicates our response as the narrator 'tips the balance in Shechem's favour'. ${ }^{45}$ Dinah herself, according to Fewell and Gunn, sees a marriage as the best way forward and that is what Shechem offers. ${ }^{46}$ She chooses to remain in his house until the wedding. ${ }^{47}$ The

38 So Jerome, Letter CVII.6, XXII.25; Luther, op. cit., 93; Calvin, Commentary, 218; Gervase Babbington, Works Containing Comfortable Notes upon the Five Books of Moses (London, 1615), 139-40; Henry, Exposition, 112.

39 St Bernard, 124-25; Ancrene Wisse, 68-69.

40 To follow the whole debate one needs to read Meir Sternberg's original chapter in The Poetics of Biblical Narrative: Ideological Literature and the Drama of Reading (Bloomington: Indiana University Press, 1987), ch. 12; D. Fewell and D. Gunn's response, 'Tipping the Balance: Sternberg's Reader and the Rape of Dinah' in $J B L 110 / 2$ (1991) 193-211; M. Sternberg's reply, 'Biblical Poetics and Sexual Politics: From Reading to Counter Reading' in $J B L$ $111 / 3$ (1992) 463-88; and Paul Noble's assessment, 'A "Balanced" Reading of the Rape of Dinah: Some Exegetical and Methodological Observations', Biblical Interpretation IV.2 (June 1996) 173-203.

41 Fewell \& Gunn, 'Tipping', 194.

42 Fewell \& Gunn, 'Tipping', 194.

43 Fewell \& Gunn, 'Tipping', 195.

44 Fewell \& Gunn, 'Tipping', 195.

45 Fewell \& Gunn, 'Tipping', 196-97.

46 Fewell \& Gunn, 'Tipping', 210, and S.P. Jeansonne, The Women of Genesis: From Sarah to Potiphar's Wife (Minneapolis: Fortress, 1990), 95, use Dt. 22:28-29 to support Dinah's right to marry Shechem. There are, however, three problems with this. For a start, Dt. 22:28-29 may not even refer to a rape case (so G.P. Hugenberger, Marriage as Covenant: $A$ Study of Biblical Law and Ethics Concerning Marriage Developed from the Perspective of Malachi [Leiden: Brill, 1994], 225-260). Second, the negotiations in Gn. 34 presuppose 
narrator is calling for a 'compromised, but realistic, resolution' ${ }^{48}$ In contrast to the reformed rapist we see the aggressive brothers of Dinah who care only for their honour (not hers). In mindless revenge they murder, plunder and rape a whole city ${ }^{49}$-an act that is grossly disproportionate-and they cannot see that Shechem is trying to make restitution for his crime. ${ }^{50}$ Having no concern about what is best for Dinah they take her against her will from the house of Shechem and kill the reformed fiancé, the only person who will allow her a voice. ${ }^{51}$ Dinah must be seen as a young woman with her own choices but the brothers only see a helpless girl needing to be rescued from herself and her fiancé. 52

Scholz ${ }^{53}$ argues that Fewell and Gunn's approval of the marriage of the rapist to the rape-victim makes the status of their interpretation as a feminist reading of Genesis 34 suspect. ${ }^{54}$ She claims that biblical texts are always read from some non-neutral perspective and that true feminist readings must be 'from the perspective of the subjugated, that is the rape victim-survivor'. ${ }^{55}$ To illustrate how Genesis 34 has not been read from that perspective she argues that 19th Century German commentaries on Genesis 34 paralleled contemporary German medical attitudes towards rape. They marginalised it, distrusted and condemned the victim, and claimed that love can make rape 'not so bad'. ${ }^{56}$ Thus the 'commentaries of Genesis 34 were not developed from the perspective of Dinah. They reflected the perspective of the powerful.'57 She then rereads Genesis 34:1-3 from Dinah's perspective ${ }^{58}$ in such a way as to make the horror of rape the key

that the family of Dinah can refuse the marriage which indicates that a law more like Ex. 22:15-16 than Dt. 22:28-29 was at work. Finally, as Sternberg has shown ('Sexual Politics', 482-83), even if Dt. 22 is about rape it would not, from a Mosaic perspective at least, be applicable to a Hivite.

47 Fewell \& Gunn, 'Tipping', 200.

48 Fewell \& Gunn, 'Tipping', 197.

49 Fewell \& Gunn, 'Tipping', 205.

50 Fewell \& Gunn, 'Tipping', 200-201.

51 Fewell \& Gunn, 'Tipping', 211.

52 Fewell \& Gunn, 'Tipping', 211.

53 S. Scholz, 'Through Whose Eyes? A "Right" Reading of Genesis 34' in A. Brenner (ed.), Genesis: A Feminist Companion to the Bible (2nd Series) (Sheffield: Sheffield Academic, 1998), 150-71.

54 Scholz, 'Whose Eyes?', 151.

55 Scholz, 'Whose Eyes?', 151.

56 Scholz, 'Whose Eyes?', 154-60.

57 Scholz, 'Whose Eyes?', 159-60.

58 Scholz, 'Whose Eyes?', 164-71. 
focus. Verse 2, she argues, emphasises Shechem's increasing use of violence against Dinah so that $\mathrm{v}$. $2 \mathrm{~b}$ describes the action of rape..$^{59}$ Her treatment of v. 3 is her most original contribution to the study of the chapter. ${ }^{60}$ She argues that it is not intended to reflect positively upon Shechem. She reads it as follows: 'His (sexual) desire (נפשר) stayed close to (בדינה) Dinah'. The context then requires us to read the second line as 'and he lusted after (ויאהי) the young woman'. Following Fischer61 she reads the final line as, 'and he attempted to soothe (וידבר על-לב הנער) the young woman'. In other words, he has to calm her because she does not consent. 'This interpretation of Gen. 34:1-3 indicates that several verbs describe the selfishness and the disregard Shechem held for Dinah. The interpretation confirms the notion of the Women's Movement that rape is primarily an act of violence rather than a sexual act. When rape is accentuated, love talk is not involved.' 62

Despite their stark differences, both these studies argue that the story must be read from the woman's perspective and that one can, to some extent at least, read with the text to restore Dinah's honour as a person with value and choices.

\section{Reading against the Biblical Text}

Within Genesis 34 both patriarchy and androcentrism are issues of concern to feminist readers. The problem with patriarchy is seen most clearly in the way in which marriages in Israel are arranged without any reference to the wishes of the girl involved. Genesis 34 reflects this widespread custom. Naomi Segal complains that 'Dinah is an object of exchange so blank that to violate her is to enter nothing but instead to "take" something-from whom? not from her. The text is singularly clear in exposing the discursive economics of male sexuality, with its exchange of object-females among subjectmales ... The shared norm of all the men is expressed in the narrowly ambiguous pronoun that the defines the crime as "a disgrace to us".'63

59 Scholz, ‘Whose Eyes?', 165-68.

60 Scholz, 'Whose Eyes?', 168-71.

61 G. Fischer, 'Die Redewendung דבר על-לב im AT: Ein Beitrag zum Verstandnis von Jes 40:2', Biblica 65 (1984) 244-50.

62 Scholz, 'Whose Eyes?', 171.

63 N. Segal, Review of The Poetics of Biblical Narrative, VT 38 (1988) 247-48. 
Perhaps more worrying seems to be the clear androcentrism of a story which, although it involves the rape ${ }^{64}$ of a woman, is all about men and their reactions. The silence of Dinah is the central issue of concern for most feminist readers. Why is her view not directly represented? Why is she never consulted about what she would like to happen vis-à-vis marriage? The worry is that it is not simply biblical interpreters who ignore her perspective, but the biblical narrator himself.

Rashkow ${ }^{65}$ objects to the androcentrism reflected in the way that Dinah is defined in relation to men. She is Jacob's daughter. She is the brothers' sister. Why is she never simply Dinah-a woman with her own identity? ${ }^{66}$ As I do not think this a particularly strong objection I shall deal with it now rather than later. Rashkow is very individualistic in her assumptions and seems to presuppose that people are only seen most fully as people when they are considered as isolated individuals who are fully 'themselves' on their own. This notion of the solitary self has been subjected to sustained criticism by philosophers and theologians in recent years. The 'self' is a 'selfin-relation': part of what it is for me to be me is to be someone's son, someone's brother, someone's father. Feminism itself has played an important role in rediscovering the crucial place of relationality in identity ${ }^{67}$ Thus Genesis 34 does not demean Dinah by referring to her as 'Jacob's daughter' or 'their sister'. On top of that, the men are described as 'her father' and 'her brothers' indicating that their identity is formed, in part, by their relation to her. Also she is related to Leah in v. 1 who is a female and thus it seems to me that this criticism really misses the mark. In fact, all the relational participant

64 L. Bechtel, 'What If Dinah Was Not Raped (Genesis 34)?', JSOT 62 (1994) $19-36$, is the only feminist scholar I have come across who challenges this consensus. I critique her view in my thesis.

65 I. Rashkow, 'Daughters and Fathers in Genesis ... or, What Is Wrong with This Picture?' in D.J.A. Clines \& C. Exum (eds.), The New Literary Criticism of the Hebrew Bible (Sheffield: Sheffield Academic, 1993), 250-65.

66 Rashkow, 'Daughters', 104-106. See too Segal, Review, 248.

67 Margaret Kock ('A Cross-Cultural Critique of Western Feminism' in M.S. Van Leeuwen [ed.], After Eden: Facing the Challenge of Gender Reconciliation [Grand Rapids: Eerdmans, 1993], 70-113) argues that Western feminism has often made the mistake, among other things, of assuming that Western views of individual autonomy are essential to the liberation of women. Feminists from non-western cultures have rightly objected and refused to see the necessity of the abstracting women from the network of social relations within which they find their sense of identity. Western feminists have usually taken these criticisms seriously. It seems to me that Rashkow is stuck in an Enlightenment-Feminist mode of thought in her criticisms here. 
references Dinah receives reinforce her value. She is not just another woman to the Israelites but a sister and that is why they are so angry at the rape.

Rashkow raises another objection to the narrator in Genesis 34 claiming that 'a repeated theme in biblical narratives is the daughter's transgression against her father and subsequent departure from the closure of the house. For example, Dinah 'goes out', is raped (Gn. 34:1-2), and is then 'narratively banished from the text'.68 Rashkow here seems to accept the 'classical' reading of Dinah's 'going out' as an excursion condemned by the narrator. My first task in the next section will be to question this view but it seems appropriate, at this point, to make a preliminary criticism of Rashkow's argument, for she only gives two examples of this supposedly 'repeated theme': the first is Genesis 34 and the second is Jephthah's daughter in Judges 11. Apart from the fact that two examples would not be enough to establish the claim, it seems to me that neither of the examples provides any evidence for the proposal. Jephthah's daughter does not transgress against her father in any straightforward sense and the text of Genesis 34 says nothing of Dinah's rebellion against Jacob. Nevertheless, Rashkow, in line with the classical interpreters, clearly thinks that Dinah's 'going out' is condemned by the narrator and she subjects that condemnation to a feminist-psychoanalytic critique. ${ }^{69}$

\section{Dinah's Honour: Some Reflections}

\section{Does the Narrator Disapprove of Dinah's 'Going Out'?}

Given the agreement between some feminist readers such as Rashkow and 'classical' readers it is appropriate to begin with a reassessment of the view that the narrator condemns Dinah for 'going out'.

68 Rashkow, The Phallacy of Genesis, 67.

69 Another complaint about Genesis 34 is the way in which insult is added to injury by using Dinah's violation as an 'excuse' for victimising Canaanites (A.L. Laffey, An Introduction to the Old Testament: A Feminist Perspective [Minneapolis: Fortress, 1988], 41-44). Men typically use the rapes of women to justify wars and Genesis 34 is no exception (see A. Keefe, 'Rapes of Women/Wars of Men', Semeia 61 (1993) 79-94. I do not intend to take up this challenge in what follows for I argue in my thesis that the narrator is not trying to defend the massacre. 
(a) Does N'צ" Indicate a Narratorial Disapproval of Dinah? The first thing to refute is Sarna's claim that the verbal stem $\$ \mathbf{S}^{\prime \prime}$ can connote 'coquettish or promiscuous conduct' ${ }^{70}$ Jacob Neusner also comments that, "the verb "go out" when associated with a woman carries the sense of "awhoring". ${ }^{71}$ Neither Sarna nor Neusner provide any evidence for this assertion. Wenham tentatively provides some support for the claim by observing that in the Laws of Hammurabi 141 the cognate Akkadian verb wașu 'describes a housewife who conducts herself improperly outside her home, and the targums translate "cult prostitute" as "one who goes out into the countryside". ${ }^{72}$ However, that one example of a cognate verb can be produced in which a woman 'goes out' in a dubious fashion is very weak grounds for the claim that the Hebrew verb itself carries bad connotations. For a start, we cannot make a simple transfer from Akkadian to Hebrew. Secondly, that a verb in some contexts can carry negative overtones does not suggest that the verb carries those connotations inherently. We shall see below at least one 'whorish going out' from the Hebrew Bible but this simply does not show that all women 'going out' were viewed negatively. That the later Jewish targums spoke of cult prostitutes as women who 'go out into the countryside' does not establish that women 'going out' carried sexual overtones whatever the context nor even that the sexual usage of $\mathbf{S W}^{\mathrm{M}}$ goes back to the time when Genesis was written. We need to study the 'goings out' of women in the Hebrew Bible itself. On inspection the Emperor's new prostitute vanishes into thin air. All the Qal uses of $\$$ ' predicated of females can be categorised as follows:

- Genesis 24 is full of women who 'go out' to collect water (vv. 11, $13,15,43,45$. See also $1 \mathrm{Sa}$. 9:11) yet it certainly cannot be said that 'coquettish or promiscuous conduct' is connoted.

- It seems to have been quite common for groups of women to 'go

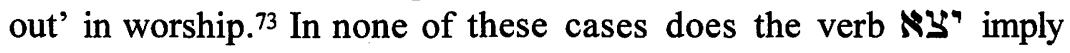
improper behaviour (Ex. 15:20; Jdg. 11:34; 21:21; 1 Sa. 18:6; Je. 31:4).

70 N.M. Sarna, Genesis (Philedelphia: Jewish Publication Society, 1989), 233.

71 J. Neusner, Genesis Rabbah: The Judaic Commentary to the Book of Genesis (3 Vols.; Atlanta: Scholars', 1985), 146.

72 G.J. Wenham, Genesis 16-50 (Dallas: Word, 1994), 310.

73 See C. Meyers, 'Miriam the Musician' in Brenner (ed.), A Feminist Companion to Exodus to Deuteronomy, 207-230. 
- Most of the 1,068 uses of the "S" stem simply denote someone moving from one place to another. It is not surprising that it is used of women in this way (Ru. 1:7; 2:22; 2 Ki. 4:21, 37; 8:3).

- The OT often describes women who 'go out' to meet people. This category includes Leah (Gn. 30:16), Dinah (34:1), Jael (Jdg. 4:18, 22) and Michal (2 Sa. 6:20). The only case in which a woman 'goes out' as a prostitute is Proverbs 7:10,15.

- Some miscellaneous examples of the verb $\boldsymbol{\aleph}$ ' predicated of females include 'going out' in divorce (Dt. 24:2), and in approved 'romantic' contexts (Ct. 1:8; 3:11). ${ }^{74}$

- Women can also be freed ('go out') from slavery (Ex. 21:3, 7, 11).

What we can say with certainty is that when the verb $\mathbf{N S}^{\prime}$ is used of women it does not carry any automatic negative connotations. The vast majority of the above women who 'go out' are not being implicitly condemned for having done so. It all depends on what the women 'go out' to do, thus Sarna and Neusner are simply wrong. The closest we get to support for the traditional view if Proverbs $7: 10,15^{75}$ where a prostitute comes out to seduce a man. Clearly her 'going out' is morally suspect but let us remember that Dinah did not go out to seduce men. She went out to see the women of the land and was raped!

The rabbis in Genesis Rabbah and later commentators such as Rashi saw a connection between Leah's 'going out' to have sex with Jacob and Dinah's 'going out': As Leah went awhoring so did Dinah. ${ }^{76}$ The connection is less than convincing. Firstly, it is not fair to describe Leah's act as one of prostitution-she was married to Jacob. ${ }^{77}$ Second, there is nothing sexual about the verb $\$$ " in Genesis 30:16. The proposal Leah made was sexual but her 'going out' was merely a prerequisite for the making this proposal. Third, apart from the parallel phrases ('and Leah went out' // 'and Dinah went out') the two events do not parallel at all. Leah went out to persuade her husband to impregnate her whilst Dinah went out to

74 Other miscellaneous uses include Zc. 5:9; Je. 29:2; 38:20-23; Mi. 4:10 (the last three refer to 'going out' into exile).

75 Possibly also Jdg. 4:18 as the account of Jael's 'going out' to welcome Sisera seems to make use of sexual innuendoes; see S. Niditch, 'Eroticism and Death in the Tale of Jael' in Bach, Women in the Hebrew Bible, 305-315. However, her later 'going out' to meet Barak does not seem to have such overtones.

76 Genesis Rabbah, LXXX:I.Y.

77 And unlike a prostitute Leah paid Rachel in mandrakes for the privilege of sleeping with Jacob rather than seeking payment from her 'client'. 
see the local women and was raped. One simply cannot read off a negative assessment of Dinah from this parallel. This strategy having failed another rears its head.

Hamilton translates v. 1 as 'she went out to be seen [implied-'by the men'] among the daughters of the land' ${ }^{78}$ As we have seen the idea that Dinah went out to get 'picked up' by some dishy young bloke traces its roots way back into the history of interpretation. His reasoning is that the construction ר (to see) in the infinitive + ב is unique and thus he prefers to translate as a passive rather than an active form. However, out of 111 uses of the Qal infinitive construct of ראה in the OT there is no clear example of a passive use ('be seen'). Every occurrence is most naturally read as active ('to see'). If the narrator had wanted to say that Dinah had gone to 'be seen' he would have used the Niphal infinitive construct which always bears that sense. ${ }^{79}$ Hamilton does add that 'the active sense is possible only if one understands $b^{e}$ partitively, that is, "to see some of the women"' ${ }^{80}$ The weight of evidence would support this reading.

Perhaps, the traditionalist may reply, women could 'go out' acceptably in groups but to go out alone was seen as wrong. This is more plausible but unpersuasive. We note that Rebecca is not frowned upon in Genesis 24 for 'going out' alone before all the other women to collect water. Similarly, Rachel kept her father's sheep, apparently alone, yet there is not obvious condemnation for that. ${ }^{81}$ Having said this, I do think that it would have been considered unwise for a woman to go out alone into territory not her own. This is put very well by Naomi in Ruth 2:22, 'It will be good for you, my daughter, to go with the girls, because in someone else's field you might be harmed'. It is not that Ruth would have been seen as immoral in going out to someone else's field. Rather she would have put herself in possible danger and would be wise to find security in a group. The Dinah situation finds its most comfortable parallel with

78 V.P. Hamilton, The Book of Genesis: Chapters 18-50 (Grand Rapids: Eerdmans, 1995), 351; so too Aalders, Genesis, 154 and L.R. Kass, 'Regarding Daughters and Sisters: The Rape of Dinah', Commentary 93 (1992) 31.

79 There is some textual support for a Niphal in the Samaritan Pentateuch (followed by some of the Jewish Midrashim-see J.K. Salkin, 'Dinah, the Torah's Forgotten Woman', Judaism 35 [1986] 284-89) but the MT and

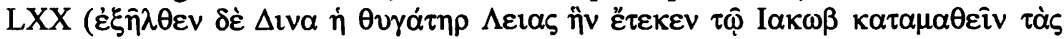

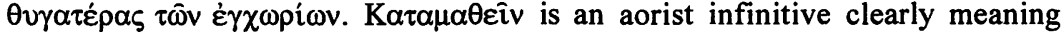
she went 'to understand' and not 'to be understood') support the Qal reading (as does Hamilton himself).

80 Hamilton, Genesis 18-50, 353.

81 Gn. 29:6-12. 
Ruth 2:22. Dinah was going out into dangerous territory-the land of the Canaanites. In doing so alone she may well have been considered to have acted naively but not necessarily promiscuously.

(b) Does the Narrator Blame Dinah? Given the mountains of blame heaped upon Dinah by classical interpreters, one is struck by the fact that at no point in the chapter is Dinah blamed for what has happened. Blame is always placed squarely on Shechem's shoulders. Shechem saw her, took her, lay her and shamed her (v. 2). Shechem 'defiled' her (vv. 5, 13, 2782) and 'did folly in Israel' (v. 7). Now it was perfectly possible for a woman to 'do folly' by engaging in illicit sexual relations ${ }^{83}$ but no mention is made of Dinah 'doing folly'. Shechem treated her as a prostitute (v. 31). No mention is made of Dinah acting like a prostitute and thus sharing in the blame. This is because in Israel, women were not held responsible in cases of rape. ${ }^{84}$

Did Dinah know what would happen to her? Did she know that she would (or might) be raped? Could she have known how her rapist would react? Could she have anticipated her brothers' response? The only action for which she is responsible is her own 'going out' and the only blame is any that may attach to her lack of wisdom.

(c) Does Genesis 34 Support Locking up Our Daughters? Interpretation is underdetermined by the text with regard to the restriction of daughters to the home. It could be used, as argued above, for Dinah's lack of wisdom in going out alone given the dangers. However, beyond that it cannot direct us. If one is already committed to the idea that women are vulnerable and best kept safe in the security of the home, as the classical readers were, then Genesis 34 certainly could be used to reinforce such a belief. Alternatively, if one was a feminist who was angered at the fact that women are preyed upon, one could equally use the text to support a 'Claim Back the Night' kind of campaign. The narrator is not especially concerned to address such issues. We may be, and we may use the text to inspire us in our reflections but we cannot use it to settle the issue either way. Either readers' response could be a legitimate one as far as doing justice to the text goes.

82 Verse 27 actually says that 'they (i.e. the now deceased men of Shechem) defiled Dinah'. Nevertheless, no blame is attached to Dinah here.

83 Dt. $22: 21$.

84 Dt. 22:25-27. 


\section{The Problem of Patriarchy in Genesis 34}

Patriarchy is simply assumed in Genesis 34 as in the rest of the Hebrew Bible where it is was neither justified nor critiqued. Does the fact that Israel was a patriarchal society make patriarchy a biblical norm for all cultures at all times? Not obviously. Let me make a few brief remarks in an attempt to set the problem posed by Israel's apparently male dominated social structures in some perspective.

First, Carol Meyers has urged great caution in this area. She argues that the concept of patriarchy needs to be nuanced to deal with differences across time and culture, maintaining that in Ancient Israel, as in some contemporary peasant societies, women had a great deal of power even if they had little authority ${ }^{85}$ and would not have (usually) found their place in society as harsh or oppressive. Biblical societies were strongly patrilinear ${ }^{86}$ but 'male dominance [was] ... a public attitude of deference or of theoretical control but not a valid description of social reality' ${ }^{87}$ Thus care ought to be taken when criticising Ancient Israelite society for it may not have been nearly as oppressive for women as it may at first look. ${ }^{88}$ It remains the case that Israel's laws and social structures are dominated by men and can be termed patriarchal so long as care is taken when so doing.

Second, the biblical metanarrative of creation, fall and restoration could provide the ground for a biblical critique of patriarchy. ${ }^{89}$ In

85 Authority is a hierarchical arrangement that may be expressed in formal legal or juridical traditions (Meyers, Discovering Eve, 41).

86 Patrilineality refers to the tracing of group membership through the father's line. The inheritance of property is also through this line. Patrilineality has been explored by Steinberg in the Genesis stories (Naomi Steinberg, Kinship and Marriage in Genesis: $A$ Household Economics Perspective [Minneapolis: Fortress, 1993]).

87 Meyers, Discovering Eve, 42.

88 Similar warnings are made by Schroer in Schottroff, Schroer \& Wacker, Feminist Interpretation, 89-91. Schroer writes that 'one must warn against comparing ancient Israelite patriarchy with that of today's industrialised, technological, and individual-orientated societies. In an agrarian culture where they are part of the process of production, women are often in positions of equal power to men even when they are excluded, for example, from politics and public activities' (ibid., 90-91).

89 See 'Living between the Times: Bad News and Good News about Gender Relations' in (ed.) M.S. Van Leeuwen, After Eden, 1-16; B. Walsh \& R. Middleton, Truth Is Stranger Than It Used to Be: Biblical Faith in a Postmodern Age (London: SPCK, 1995); F. Watson, Text, Church and World: Biblical Interpretation in Theological Perspective (Edinburgh: T \& T Clark, 1994), ch. 11 . 
creation men and women are equally in God's image ${ }^{90}$ and equally commissioned to fill and subdue the earth. ${ }^{91}$ Francis Watson believes that 'The Hebrew narrators [in Genesis 1-3] were somehow able to transcend the all-embracing, self-evident patriarchal context in which they no doubt lived and worked, in order to assert that "in the beginning it was not so". ${ }^{92}$ Genesis $3: 16$ seems to be a watershed in gender relations as sin could be seen as the origin of men ruling over their women. ${ }^{93}$ If this is correct, then oppressive patriarchy could be rooted not in the creative intentions of God but in the fallenness of the world. Redemption then restores men and women equally ${ }^{94}$ enabling men and women to receive both the Spirit and his gifts. ${ }^{95}$ One could see the patriarchy of Israel along the same lines as the divorce laws-not God's intention, but allowed due to sin-hardened hearts. ${ }^{96}$ However, now that the new age has dawned such social structures are passing away. ${ }^{97}$ This basic hermeneutic is that adopted by the majority of so-called evangelical feminists as well as by many non-evangelical, Christian feminists. It has the benefit of allowing one to recognise the patriarchy of Israel without seeing it as normative. It also seeks out a critical principle with which to critique patriarchy that has genuine claims to be Christian and internal to the biblical canon rather than an alien principle rooted in secular ideology. .8

$90 \mathrm{Gn} .1: 26$. There are many and diverse feminist interpretations of this crucial text.

91 Gn. 1:28.

92 Watson, Text, Church and World, 194.

$93 \mathrm{Gn} .3: 16$ has generated many feminist studies among which are P. Bird, 'Genesis 3 in Modern Biblical Scholarship' in Bird, Missing Persons, 174-93; A. Bledstein, 'Are Women Cursed in Genesis 3:16?' in A. Brenner (ed.), Feminist Companion to Genesis, 142-45; C. Meyers, 'Gender Roles in Genesis 3:16 Revisited' in A. Brenner (ed.), Feminist Companion to Genesis, 118-41 (see too Meyers, Discovering Eve); P. Trible, God and the Rhetoric of Sexuality (London: SCM, 1978), 126-28.

94 Gal. 3:28.

95 Acts $2: 16-17 ; 1$ Cor. $11: 3 \mathrm{ff}$.

96 Mt. 19:4-9 pars.

97 The persistence of patriarchy in the NT could be seen in terms of the tension between the 'now' and the 'not yet' which marks the present experience of the Christian. The patriarchy of the NT is a radically Christianised and subversive form of patriarchy but it is patriarchy none the less. The question is: was the patriarchy of the NT merely a concession to culture or a norm for all Christians?

98 Thistleton criticises Fiorenza and Daly for finding their critical principle outside the biblical text and not being open to dialogue with the text from which one can learn. Instead one approaches the text with all the answers and simply measures the text against them (New Horizons, 442-50). Francis 


\section{The Problem of Androcentrism in Genesis 34}

It is true that there is no direct indication of Dinah's perspective on the crime in Genesis 34. Before commenting on this it is worth pointing to some indirect indicators of how she felt.

First, we are told in 34:3 that Shechem 'spoke to her heart' which clearly indicates that she was distressed and Shechem consequently took steps to calm her. ${ }^{99}$

Second, the sons (and Jacob?) saw the rape as an act which treats Dinah as a prostitute (v. 31) and thus 'defiles her' (vv. 5, 13, 27). It is 'folly in Israel' (v. 7). It is sometimes assumed that this is merely the men's view on the crime and not Dinah's. The marriage, we are told by the sons, is 'a disgrace to us' and both Fewell \& Gunn and Segal take the 'us' here to refer to the sons in contrast to Dinah. Segal thinks that we ought to see the rape from Dinah's perspective-as her autonomy being cruelly violated. ${ }^{100}$ However, it is most unlikely that Dinah would see her rape as modern western women would. ${ }^{101}$ For us, rape is primarily a violation of a woman's autonomy and bodily integrity, but that is no reason to imagine that Dinah would see a violation of her autonomy as primary. It may be the case that the sons imagine that Dinah will see the rape from the same perspective as themselves and they cannot see that even if this is so it would be much more than that to her. They do fail to perceive fully her perspective and this is a weakness on their part. Nevertheless, I would imagine that she would perceive her rape in much the same categories as her family: as 'folly' and as 'defiling'. ${ }^{102}$ Now they are presuming on Dinah here, for they have not actually consulted her (she was inaccessible at Shechem's house), but presumably she

\footnotetext{
Watson finds the redemption of an otherwise oppressive Bible in the claim that the elements in the canon which resist oppression are not mere 'scattered fragments' but belong to the 'fundamental structure' of that very canon (Text, chs. 9-11). Thus the critical principle used to subvert many biblical narratives is not merely secular and external to the Bible but also religious and internal to it (ibid., 190).

99 Rightly, Scholz, 'Whose Eyes?' Incidentally, Fewell \& Gunn are quite wrong to take Shechem's speaking to Dinah's heart as a periocutionary act which wins her over to his cause ('Tipping', 196). Sternberg has clearly demonstrated that it indicates nothing about Dinah's response to Shechem's soothing words ('Sexual Politics', 476-78). Thus the text does not indicate that Dinah came to love Shechem.

${ }^{100}$ Segal, Review, 247.

${ }^{101}$ Rightly Keefe, 'Rapes of Women', 79.

102 One could argue that Dinah had internalised a male perspective on rape but even if that were so it would still remain her perspective.
} 
shares the basic Israelite perspectives on rape and exogamy-the same one her brothers would have. 103

The considerations above suggest that if it is legitimate to reimagine the story from Dinah's perspective, then care ought to be taken to avoid anachronism - to imagine that Dinah is a modern western woman with modern western values. We need to try to understand how the rape would be seen within an Israelite worldview. Attempts to restore Dinah's voice must ring true to the ancient cultural context.

However, we are still left with the problem that the story, quite clearly, does not take Dinah's perspective into consideration and this raises the legitimate concern that the person most affected by the crime is silenced, not only by the men who negotiate over her fate, but also by the narrator himself. What can we say about this?

Let us first note that every story is told from some perspective. Any incident can be told from the perspective of any of the parties directly or indirectly involved. The Genesis 34 events could be narrated from the perspective of the Hivite town dwellers, Jacob, the sons, Shechem, Dinah, or from any number of other perspectives. Each version would be, to some extent, a different story. Every story is told for some reason. This leads to a selection and organisation of the material so as to make the desired point. Every telling of a story has to marginalise some characters and events so as to focus on whatever it is the story teller wishes to focus on. That Dinah is marginalised in the plot need not imply that she is not morally relevant but only that in the telling of this story the rape is not the main focus of the plot. Unless one believes that every story which includes a rape must be a story about rape there is no prima facie problem with the narrator's strategy here. Nobody would suggest that the rape is not taken seriously in Genesis 34 -it leads to a massacre.

Nevertheless, even though the rape is taken seriously it is done so from a male angle. Is Dinah's view of the crime seen to be irrelevant? To some extent it depends on whether one feels that the lack of a certain perspective in the biblical narrator's telling of a story rules out the legitimacy of that perspective. In this case, we could ask, 'Does the fact that the narrator's chosen function for this story makes no use of Dinah's perspective rule out the legitimacy or

${ }^{103}$ Incidentally, to imagine, as some have, that Dinah would enjoy the rape owes more to male fantasising than to textual evidence or studies of actual rape cases. 
relevance of Dinah's perspective?' Clearly that depends on what we mean by 'relevance'. Dinah's perspective is not relevant to the point our narrator wants to draw attention to in his telling of story. This, however, is not to say that it is not relevant to any legitimate telling of the story. Stories may be open to the possibility of a range of uses of, and perspectives on, the events so long as those perspectives cohere with their overall worldview. From the fact that Dinah's view is not found in Genesis 34 one cannot infer that Dinah's view does not matter, nor even that Dinah's view does not matter to the author. ${ }^{104}$ One can only infer that Dinah's view is not relevant to the point that the narrator wants to make in his use of the story here.

It could be argued that the narrator should have set out to see her side of things. Her view may not suit his purposes but that is merely because his purposes are androcentric and so the feminist critique still has bite. However, although that the task of presenting Dinah's view would be very worthwhile why must the narrator do this? If the narrative somehow made Dinah's perspective illegitimate or irrelevant in a broader sense (rather than simply for the purposes in mind for his particular use of a story) then we have strong grounds for deep concern. However, as I have already said, we cannot infer from Dinah's silence that the views of the victims of rape do not matter. ${ }^{105}$

A deeper concern is that Dinah's silence is a manifestation of 'the androcentric values and the androcentric worldview of the biblical narrative'106 in which rape was considered a crime against men (husbands and fathers) and not women. ${ }^{107}$ Consider Thistlethwaite's definition of rape in Israel: 'Biblical rape is theft of sexual

\footnotetext{
104 I hesitate to say 'narrator' as it seems to me that a narrator has no existence beyond the text and consequently one cannot talk of their holding views which are not expressed in the text (as authors can).

105 There are possible explanations for Dinah's silence which do not reflect the view that her perspective is irrelevant because it is female. For instance, Sternberg ('Sexual Politics') has suggested that Israelite rules on exogamy would rule the marriage out of court and that, consequently, Dinah's views for or against the marriage were really irrelevant, but then so too were those of any of the male characters. It is not only Dinah's views but also Jacob's which are absent from the story. A fascinating alternative view on Dinah's silence is that of feminist scholar Alice Keefe ('Rapes of Women').

106 C. Exum, 'Who's Afraid?', 145.

${ }^{107}$ See for instance, C. Pressler, 'Sexual Violence and Deuteronomic Law' in A. Brenner (ed.), Feminist Companion, 102-112. Pressler argues that behind the laws on violence against women lies the assumption that 'female sexuality is male property' (p. 112).
} 
property'. ${ }^{108}$ Rape, on this analysis, has nothing to do with a crime against the woman herself. Thistlethwaite is correct, in my view, that rape in Israel was seen as a crime against the father (if the girl was unmarried) or the husband. Children were under the authority of their fathers and one was not allowed to engage in sexual relations with a daughter unless the father had given permission for marriage. However, she is, I suspect, wrong if she intends to imply that rape in Israel was only an 'offence' against the father or the husband. Rape was also seen as wronging a woman herself. Consider the words of Tamar to Amnon in 2 Samuel 13:12-13 before the rape: 'Don't force me ... What about me? Where could I get rid of my disgrace?' Consider her words after he rapes her and then casts her out in verse 16: 'Sending me away would be a greater wrong than what you have already done to me'. Notice, the crime is, from her perspective, primarily against her and not her father. ${ }^{109}$ Furthermore, it is misleading, in my view, to talk of wives in Israel as sexual property. ${ }^{110}$ Nevertheless, in spite of all that I have said, it remains the case that Genesis 34, along with most OT narrative, is androcentric. As I consider Dinah and Leah's views to be valuable it

${ }^{108}$ S.B. Thistlethwaite, "You May Enjoy the Spoil of Your Enemies"-Rape as a Biblical Metaphor for War', Semeia 61 (1993) 59. Rashkow similarly writes, 'And as the Genesis 34 narrative of Jacob's daughter Dinah makes clear, rape is not considered a violation of the daughter so much as a theft of property that deprives the father and necessitates compensation to him' ('Daughters and Fathers', 70). Besides my comment above to the effect that rape was also a crime against women in Israel, I think that it is dubious to claim that there is any form of compensation to Jacob in Genesis 34. Shechem offers a generous but standard payment of a מוהר for the marriage. There is no obvious compensation mentioned except the generous amount but that is presented as Shechem's desperate attempt to persuade Jacob to allow the marriage and not a compensation.

${ }^{109} \mathrm{It}$ could be argued in response that 2 Samuel 13 presents Tamar's personal female perceptions of her rape and not the public male perceptions embodied in law codes such as those Pressler discusses. This distinction is too sharp. Tamar's perceptions would reflect the social attitudes of ancient Israelite society which were broader than the law codes but which played an important role in Israelite personal and social ethics (on the complex and obscure relations between OT laws and social norms see Cyril S. Rodd, Glimpses of a Strange Land: Studies in Old Testament Ethics [London: T \& T Clark, 2001]). Such social attitudes were admittedly shaped by Israelite patriarchy so that the crime against the woman was not primarily one of violence against her autonomy but a crime against her honour and her chances of marriage. Nevertheless, rape was still seen as an offence against the woman as well as her father or husband (contra Rodd, Glimpses, 263-69).

${ }^{110}$ Hugenberger, Marriage as Covenant, ch. 6; C.J.H. Wright, God's People in God's Land: Family, Land and Property in the Old Testament (Carlisle: Paternoster, 1990), ch. 6. 
is at least inadequate for an analysis of sexual justice or the ethics of rape.

The outcome of this discussion seems to me threefold. First, the fact that Genesis 34 is told from a male perspective does not, in and of itself, make it illegitimate for such perspectives are surely relevant. Second, the androcentricity need not even make it problematic in $a$ strong sense for such perspectives are not necessarily inconsistent with female ones and do not rule out the latter's legitimacy. Third, if we grant the legitimacy of a female perspective then we grant that there is more to be said about the incident at Shechem than is said by Genesis 34 . This need not be a threat to Genesis 34 but it may point towards the legitimacy of some kind of re-imagining the story from the perspective of the women involved (Leah, Dinah and the Hivite women). This leads me on to a recent hermeneutical proposal by Richard Bauckham. ${ }^{111}$

Bauckham argues that the Bible contains several narratives, or parts of narratives, which are gynocentric (seen from a female perspective). He pays special attention to the book of Ruth demonstrating how it reflects female perspectives on its subject matter. ${ }^{112}$ 'The value of Ruth as women's literature is precisely that it renders visible what is usually invisible'. ${ }^{113}$ Now that a book such as Ruth is included within the canon serves as a counterbalance to the majority of androcentric texts. But it does more than that: 'By revealing the Israelite women's world which is elsewhere invisible in biblical narrative it makes readers aware of the lack of women's perspectives elsewhere and it also authorises them to supply just such a women's perspective elsewhere, expanding the hints and

${ }^{111}$ R. Bauckham, Is The Bible Male? The Book of Ruth and Biblical Narrative (Cambridge: Grove Books, 1996); 'The Book of Ruth and the Possibility of a Feminist Canonical Hermeneutic', Biblical Interpretation V.1 (1997) 29-45.

112 Which is not to claim that it was written by a female (Bauckham, 'Is the Bible Male?', 6-7, 'Book of Ruth', 29-31) nor is it to claim that Ruth subverts the patriarchal structures of OT society for it does not. 'Ruth is the paradigmatic upholder of patriarchal ideology' (E. Fuchs, 'Status and Role of Female Heroines in the Biblical Narratives' in A. Bach [ed.], Women in the Hebrew Bible, 78). Fuchs sees the book of Ruth as a book from a man's world and for a man's world but, although she is correct in seeing the book as one which operates within the norms of patriarchy, she fails to appreciate the degree of gynocentrism observed by Bauckham and others. See A. Brenner (ed.), A Feminist Companion to Ruth (Sheffield: Sheffield Academic, 1993) for various essays highlighting the book of Ruth as 'a female text' (p. 14), 'a collective creation of women's culture' (p. 139) and 'an expression of women's culture and women's concerns' (p. 143).

113 Bauckham, 'Is the Bible Male?', 14. 
filling in the gaps which they can now see to be left by the narratives written purely or largely from a male perspective'. ${ }^{114}$ He concludes, 'Even though the majority of biblical narratives are androcentric, there are enough authentically gynocentric narratives to counteract this dominant androcentricity, provided we allow them to do so'. ${ }^{115}$ Bauckham is saying that the biblical canon itself could legitimate such an imaginative approach to its androcentric narratives. ${ }^{116}$

A traditional Christian will need to ask what the connection is between the voice of the narrative and the voice of God. Perhaps it would be better to speak of the voices of a narrative for biblical narratives draw in different voices and different perspectives. Genesis 34 is a case in point, for we have already clearly distinguished the perspectives of Jacob, his sons, Shechem, Hamor and the Hivite men. Sternberg has shown how the narrator skilfully brings all the divergent voices of the characters into play, mediating between them and leading the reader towards certain evaluations of those characters. That is to say that the narrator too has a perspective and a voice and he aims to lead the reader to share this view. Should we identify the narrator's perspective with God's? ${ }^{117}$ Sternberg thinks that the narratorial voice is actually presented as a prophetic voice identified with God's. ${ }^{118}$ However, this is questionable ${ }^{119}$ and, even if Sternberg is right, from a canonical view God's perspective on any particular incident cannot be exhausted by that of a narrator even if the narrator captures part of it. We could say then that the narrator's perspective is only 'identified' with God's in this weaker sense. The canon of the Hebrew Bible and the New Testament both endorse multiple, authorised perspectives on the same events indicating that no single telling of the event claims to pick out every morally and theologically salient feature, and numerous different perspectives can stand side by side in harmony. What, for instance, is God's perspective on Jesus? That of some particular Gospel writer? Of Paul? Of Peter? Of Revelation? God's

\footnotetext{
${ }^{114}$ Bauckham, 'Is the Bible Male?', 17.

115 Bauckham, 'Is the Bible Male?', 23. 116 And, of course, a male reimagining of the gynocentric sections of Ruth is
also legitimated.

117 The notion that a God's-eye view is neutral in some way is not a Christian one. A God's-eye view would be one in full possession of the facts and pure in its moral judgements.

${ }^{118}$ Sternberg, Poetics, ch. 2.

${ }^{119}$ N. Wolterstorff, Divine Discourse: Philosophical Reflections on the Claim That God Speaks (Cambridge: CUP, 1995), 245-52.
} 
view cannot be exhausted by any one of their perspectives nor by their cumulative totality.

Nevertheless, for the traditional Christian, all the biblical narrators' perspectives are divinely authorised as appropriate ones and together they shape and inform readerly perspectives. None of them would be seen to conflict with divine perspectives ${ }^{120}$ and God speaks through them to his people recommending ways of seeing situations. However, we should not infer from the authorised nature of biblical narratives that the narrator says all that is worth saying or exhausts the divine perspective. This seems to me to make imaginative retellings of Dinah's feelings unthreatening to the canonical account-at least in principle. So long as they are not thought by the Christian community to have the status of the canonical telling the enterprise seems perfectly legitimate.

Some reflections on biblical authority may be in order here. One cannot move without thought from the claim that a particular biblical text was inspired by God to the claim that it is normative or authoritative. Classical Christian views of the Bible have seen divine authority mediated through the canon as a whole rather than its individual parts in isolation. ${ }^{121}$ The Bible is not normative because it is composed of normative parts as if normativity is found as much in those parts in isolation. Nor is normativity something which supervenes upon the complex intertextual links of the completed canon as if at some point the collection 'went critical' and suddenly, as if by magic, the authority appeared. Rather, I suggest, each part of the whole is inspired and, in its original contexts, mediated some mode $^{122}$ of divine authority. However, when incorporated within the canon the way in which they are normative is modified by interactions with fellow texts. Thus any part of the Bible can only

\footnotetext{
${ }^{120}$ Perhaps Wolterstorff would nuance this to suggest that God would be saying what the narrator is saying unless we have good grounds for thinking that God would not be saying that (ibid., ch. 12). Exactly what would count as good reasons is then a crucial question as the door could be open to anybody to reject illocutionary stances of biblical narrators on the grounds that they think that God would never take such a stance. The whole notion that God appropriates human illocutionary stances could be ultimately undermined in this way.

${ }^{121}$ Some feminists see the canon itself as a patriarchal construction. For a brief but helpful critique see Bauckham, 'Book of Ruth', 44-45.

122 Clearly different genres mediate divine authority in different ways (compare the Ten Commandments with Proverbs) and thus I speak of modes of authority. Further clarification is obviously required here. It may be that the notion of authority is not elastic enough to cover all the biblical texts and should be abandoned in some cases.
} 
function normatively for the Church when seen within the context of the whole. Clearly, as the canon has grown and the plot line has moved on, the way in which different texts function normatively changes.

So, returning to feminist concerns, even if a biblical narrative sets out models for appropriate wifely behaviour (say) one cannot simply assume that those models are still normative today in the same way as they were when the texts were originally produced. It seems to me that the very nature of the canon invites a certain kind of relativising of texts in light of the whole. Biblical narratives can, in principle, be supplemented and 'relativised' by other biblical texts ${ }^{123}$ and by archaeological finds without threatening their inspiration or their authority. In the context of gender issues the kind of relativising that I am proposing does not relativise the androcentric texts in every respect but simply in their androcentrism. ${ }^{124}$

Let me bring these reflections to Genesis 34 and briefly explore the limits and legitimacy of restoring the female perspectives. Genesis 34 simply does not provide the information from which to construct Dinah's viewpoint, let alone those of Leah or the Hivite women. In the story her view is not a gap that needs to be filled in order to make sense of the narrative but a blank-an information gap to which the narrator does not draw attention. ${ }^{125}$ Herein lies the potential danger of 'authoring the secret diaries of Dinah'126 - 'Anyone who wanted answers to these questions [about Dinah's view] would have no option but to invent their own'. ${ }^{127}$ One could invent a range of totally contradictory perspectives for Dinah and none of them could claim to be anything more than the imaginative reconstructions of the reader. This is only a problem if one thinks that one is finding the 'right' answer given by the text rather than supplementing the text with informed yet imaginative stories. Some reflections are in order.

\footnotetext{
${ }^{123}$ I suggest that the biblical plot line itself prioritises certain key texts and themes theologically over others. For instance, Gn. 1-2 has long been recognised as carrying a priority over Esther (say) or Deuteronomy in theological considerations of gender relations. This is because Gn. 1-2 reflects the way God set things up in the beginning prior to sin's distortions (see Mt. 19:1-8).

124 With Bauckham, 'Book of Ruth', 44.

125 On gaps and blanks see Sternberg, Poetics, 235-58.

126 Noble, 'Balanced Reading', 200.

${ }^{127}$ Noble, 'Balanced Reading', 198.
} 
An exegesis of Genesis 34 should make no reference to Dinah's views as they are simply irrelevant to the story-telling of the chapter. ${ }^{128}$ This does little for issues of women's justice or dignity, but I have attempted to argue that it need do nothing to harm them either so long as it does not legitimate the broader claim that Dinah's view does not matter at all.

If we grant, as we must, that the female views are not irrelevant, then we open up the legitimacy and possibility for imaginative, Midrashic reflections on how Dinah, Leah or the Hivite women may have felt. Such reflections will not make the pretence to exegesis, but will simply claim the status of readerly reflections using the text as a springboard and not explanations of the narrator's interests.

Such readerly reflections must be grounded upon the text and a careful reading of it and they will never replace the text. Genesis 34 will be the basis for every fresh readerly reflection. Any reflection which misreads the actual text would thereby falsify itself. The biblical narrator may not share our concerns or interests but that need not stop us reading a text from the perspective of those concerns and interests. The narrator may say things which have a bearing on our concerns and provide fuel for our own reflections. Reflections on Dinah's view on her rape could draw on the story of the rape of Tamar in 2 Samuel 13 which, I would argue, deliberately alludes to Genesis 34 . The narrator in 2 Samuel sees the importance of the view of the rape victim and a reader could thus claim scriptural support for reflecting on the Shechem incident from an imaginative reconstruction of Dinah's view. Schroer comments on 2 Samuel 13 that 'a woman reading this text will note that the narrators of the story are on Tamar's side. They declare her to be free from any guilt, stress her wisdom and thoughtfulness, and feel sympathy for her. And this is how the story of a sexual assault at the royal court is at least snatched from the jaws of the final injustice, that of being silenced. In Israel, the victims of violence are remembered.'129 Perhaps a text like Psalm 55 could also be brought into intertextual relationship with our texts also. Ulrike Bail has argued that it is a

\footnotetext{
128 Rightly, Noble, 'Balanced Reading'.

${ }^{129}$ Schottroff, Schroer \& Wacker, Feminist Interpretation, 55. Judges 19 is often seen as a text which dehumanises women in the grotesque brutality dealt to the Levites concubine. However, the text very clearly presents the rape and murder of the woman as a dreadful deed indicating how serious the decline of Israel has become. In no way is the deed presented as legitimate nor is the Levite's shocking behaviour in throwing her out to be abused excused. Her story is told and must be retold in memoriam of women victims of violence.
} 
woman's complaint to God about a sexual assault by a man close to her. ${ }^{130}$ Even if this is not correct the text could be reappropriated in such a way. Such can only enrich one's reading of scripture.

Third, for readers who consider the biblical text inspired, readerly reflections will not be able to reject the narrator's perspective as false. This is not likely to impress some feminist readers. Alice Bach argues that feminist readers must suspect and resist the biblical narrator. Clearly, such a method can and has been applied to the Bible as to many texts but prioritising an orientation of suspicion as opposed to one of trust in approaching the Christian scriptures is alien to the Christian tradition. ${ }^{131}$ Feminists may often read the Bible in this way but to do so is not to read with a traditional Christian hermeneutic. Christian Midrash on OT narratives may see the women's view as either running along the grain of the text (in line with the narrator) or perpendicular to the text (neither with nor against the narrator ${ }^{132}$ ) or against the text. ${ }^{133}$ However, if a woman's re-imagined perspective does run against the grain the text it is subverted by the narrator who, for the Christian community, retains his 'authorised perspective' which, though not complete, will not be seen to be wrong. It may be felt that this hamstrings some important feminist critiques of the Bible and I am forced to agree. Nevertheless, I believe that to surrender the fundamental biblical hermeneutic of faith for one of suspicion is to pay a price too high.

${ }^{130}$ U. Bail, 'Vernimm, Gott, Mein Geber: Psalm 55 und Gewalt gegen Frauen' in H. Jahnaw et al. (eds.), Feministische Hermeneutik und Erstes Testament (Stuttgart: W. Kohlhammer, 1994), 67-84.

131 I do not want to suggest that a feminist hermeneutic is one of suspicion as opposed to one of faith. It should be obvious from Section I that many feminists seek to combine both. My point is that a feminist hermeneutic will usually begin with suspicion and then see what is left for faith whilst a Christian hermeneutic will begin with faith and suspicion will play a role subsidiary to it. Alternatively one may tone this down and argue that any critique of the biblical narrators must be done by means of a critical principle rooted in the biblical metanarrative itself rather than one imposed from the outside (Watson, Text, ch. 11; Middleton \& Walsh, Truth, ch. 8). However, pitting the whole against its parts seems at very least problematic as a method in conservative Christian hermeneutics. I can see that the whole can complement or relativise the parts but I am very cautious about the idea that it can be used to reject the parts.

132 Much of Stephen Spielberg's cartoon The Prince of Egypt would be what I call 'reading perpendicular to the text'.

133 One could imagine that 'Telling Queen Jezebel's Story', say, would involve reading against the narrator. However, the traditional Christian will not want to subvert the narrator's condemnation of Jezebel even if they may seek to understand her in a more rounded way. The biblical narrator may not tell the whole truth about Jezebel but they do tell the truth. 